\title{
Teachers' attitudes towards job satisfaction and their students' beliefs and motivation
}

Salehi, Hadi

English Department, Faculty of Humanities, Najafabad Branch, Islamic Azad University, Najafabad, Isfahan, Iran (Hadisalehi1358@yahoo.com)

\section{Taghavi, Elham}

English Department, Faculty of Humanities, Najafabad Branch, Islamic Azad University, Najafabad, Isfahan, Iran (ela.taghavi@yahoo.com)

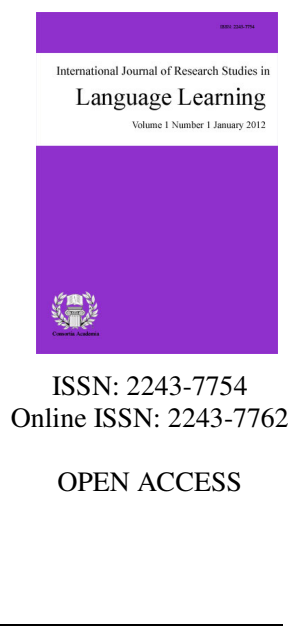

Received: 15 February 2015

Revised: 14 April 2015 DOI: $10.5861 /$ ijrsll.2015.1108

Accepted: 20 April 2015

\section{Abstract}

The issue of job satisfaction has always attracted great attention among researchers in various fields including business, industry and the public sector. This study is an attempt to investigate the relationship between teachers' job satisfaction and their attitudes towards students' beliefs and motivation. To achieve the goal, a questionnaire was designed and was administered to a sample of 340 among the English teachers, teaching in Iranian language institutes in Isfahan. After gathering the questionnaires, the quantitative data were categorized, coded and analyzed based upon the main themes and the respective research questions. The results revealed that there are empirically positive significant relationships $(t>2.56, p<0.001)$ between teachers' job satisfaction and their attitudes toward students' motivation and beliefs. The findings provide us with a better understanding of the nature of the relationship between teachers' job satisfaction and teachers' attitude toward their students' beliefs and motivation. Moreover, finding of the study could be important and helpful to designed professional development programs in order to both enhance skill and knowledge, which result in improving conditions of learning English as a foreign language.

Keywords: job satisfaction; belief; motivation; attitude; learning English 


\section{Teachers' attitudes towards job satisfaction and their students' beliefs and motivation}

\section{Introduction}

Weiss (2002) defined job satisfaction as an individual's positive measurable judgment on his or her working conditions. It is the key factor that leads to success and better performance in an organization (Amburgey, 2005; Chi-Ling, 2005). Morgan, McDonagh, and Ryan-Morgan (1995) divided job satisfaction into two types namely global job satisfaction, and facet job satisfaction. Global job satisfaction is connected with all levels of job satisfaction. It makes clear that understanding job satisfaction itself is just as essential as understanding individual employees are. The second type of job satisfaction, facet job satisfaction, depends on an individual's rank in the organization. Based on the facet job satisfaction, different levels of job satisfaction are the consequences on the divergence in employees' working experiences. In educational field, Caprara (2003, p.823) assumed that job satisfaction is "decisive element" that has a strong effects on teachers' attitudes and even performance.

Similarly job satisfaction is very significant fact resulted from self-efficacy. Researchers have shown that positive teachers' attitudes and perceptions are fundamental for effective teaching. Teachers' beliefs, perceptions and attitudes affect their practice and influence the students' performance (Eggen \& Kauchak, 2002). According to Ispir (2010), teachers' attitudes towards teaching profession can affect their classroom performance and teaching practice, and are correlated with the burnout level. As Ushioda (2003) noted, teachers being valued as a members of the group similar to their learners, they need the group development process, interaction with other members of the group, more chances of moving further in their individual learning, suitable and acceptable level of work and responsibilities. Actually, all these important factors can be available in a good work environment. Research on the school effectiveness has indicated that students' outcomes depend highly on the quality of instruction, which is interrelated to motivation and job satisfaction of the human resources (Scheerens, 2008).

As mentioned by Tercanliolu, all through the past 15 years, teachers' education research has been developed significantly in studying teacher beliefs and the connection between teacher beliefs and educational practice has already been well established. McGannon (1998) and Breen (1991) in their studies showed that teachers had many incorrect beliefs about how foreign languages are learned and those beliefs influenced teaching methods. Horwitz (1987) assumed that beliefs about language learning refer to language learners' preconceived ideas or notions on a variety of issues related to second or foreign language learning. Learners' beliefs are those ideas, feelings, and thoughts that they have about themselves, about learning situation and target community (Wesely, 2012).

The goal of the all the studies were generally to investigate the ideas of what is involved in learning a foreign languages in order to predict arguments regarding students' frustration, anxiety lack of motivation, and, that may lead to end learning foreign language(see Schumann \& Schumann,1977; Schumann,1980). In other studies especially during the last two decades, the main goal was the study of cognitive aspects of language learning. Results showed that individual learners use various strategies when they are learning a language (Altan, 2003; O’Malley Chamot, 1990; Oxford, 1992, 1993; Oxford \& Cohen, 1992; Wenden \& Rubin, 1987). Hence understanding learners beliefs about language learning would be necessary to gain better understanding of their strategies and planning they choose to learn. So it is clear and based on what Horwitz (1985) assumed if beliefs about language learning exists among people in one culture, learners would bring these beliefs with them into the class. Furthermore, it is the teachers' responsibility to put time and effort to help learners change mind and to make themselves free from the beliefs that may block language learning process.

In 2001, Peacock investigated language-learning beliefs changing. The research was in fact a longitude study in which 146 trainee ESL students participated. They studied in their three-year program at the City 
Teachers' attitudes towards job satisfaction and their students' beliefs and motivation

University of Hong Kong. The result showed no significant changes, although he reports various in three main areas including to acquire a new language means to learn a lot of new words and grammar rules, or those who learn other language are more intelligent than the other people are.

Kennedy (1996) formed a hypothesis that "real and effective change in teachers' practices can only occur through a change in their beliefs". He added behavior could derive from beliefs. As Brown and McGannon (1998) indicated letting trainees to show their beliefs explicitly is significant. The reason is that learners come to class with their beliefs which impact on both what they learn and how they learn (Richardson, 1996). In summary teachers' beliefs tend to have effects on teaching methods attitude and policies. Teaching behavior and learners' progress can be strongly affected by teachers' beliefs. In other words forming teachers' educational beliefs and attitudes can affect the way of teaching. The way of teaching could be affected by teachers' motivation. In accordance with what Dörnyei (2001) said in view of teaching as a human behavior, it is possible to talk about a general model of motivation. Consequently, we can maintain that motivation to teach determines why people decide to teach, how persistent they are, and how much effort they put into it (Dörnyei, 2001).

Motivation is an expression that people apply in daily routine when they want to talked about the causes of their behavior. Language learning motivation research has a long history in the field of second language acquisition starting from Gardner and Lambert's (1959) which is a foundation work in the bilingual context of Canada. There is also a long-standing belief of motivation research in educational psychology. Farver (2011) highlighted the fact that finding a common measure for motivation is a big challenge, especially for language learning, which is a multi-faceted phenomenon. A decade ago, Csíkszentmihályi (1997) asserted that in the field of educational psychology he was not aware of a study that would shed light on the relationship between teacher and student motivation. Many studies have been conducted that highlighted the fact that teachers' need for motivation, similar to students in order to perform better also many factors that can increase their motivation (Tziava, 2003).Teachers who experience prolonged job stress tend to have weaker relationships with the students leading to an increase in classroom management problems (Burke, Greenglass, \& Schwarzer, 1996).

Some researchers such as Ryan (1997) have claimed that it is the teacher's primary role to motivate their students, no matter how unmotivated their learners are. Furthermore, according to Landy (1989), the relationship between job satisfaction and job performance has been described as the "Holy Grail" of industrial psychologists. Rothman (1981) said that teachers with high level of job satisfaction play not only the role of a teacher but also a model. Studying teachers' job satisfaction will be helpful to both teachers and learners, hence more studies needed to be done on teachers' perception toward their jobs. It is also important to take teachers' belief and attitudes towards teaching profession and its effects on their classroom performance into consideration.

Nguni, Sleegers, and Denessen (2006) assumed that as satisfied teachers showed a lot of excitement and interest about giving more energy and time to help students achieve their academic goal, it is essential to investigate all factors that have effect on teachers' job satisfaction. So the needed information will be available to improve and give help the educational system to achieve designed goal (Perie, 1997). Thoonen (2010) examined the significance of teachers' self-efficacy beliefs and their teaching in order to propose reasons to variation in students' motivation. The researcher observed that students' motivation was positively affected by associating students' world and cooperative learning methods. However, teachers' process-oriented instructions impact negatively on their student motivational behavior. He also mentioned that the finding of the study confirmed that teachers' self-efficacy can affect both their teaching and students' motivation to learn.

The purpose of Huysma's (2007) research was to understand the beliefs and attitudes of teachers that have some possible impact on their perceptions of job satisfaction in one small rural Florida school district. A questionnaire that measured 20 factors for job satisfaction and Interviews were used to collect needed data. The result revealed that "role confusion" was indicated as a major source of job dissatisfaction for teachers. These teachers often found themselves frustrated at work because of conflicting expectations and perceptions between their professional roles as teachers and their social roles in the community. Also interview data showed that a 
Salehi, H., \& Taghavi, E.

high majority of teachers were dissatisfied because they believed other teachers to have influence and power. As a whole the research analysis of the data not only confirmed prior research suggesting that multiple factors influence job satisfaction, but also revealed that several issues which were not reported in the previous studies of rural teaching.

As teachers according to Fullen and Stiegelbauer( 1991), are still playing a crucial role in the success of the educational system, the major purpose of this study is to provide better understanding about Iranian English teachers perception of their job. Besides, the study tries to investigate the probable relationship between EFL teachers' job satisfaction and their attitudes towards students' beliefs and motivation.Specifically the objectives of this study are:

$>$ To investigate the probable relationship between EFL teachers' job satisfaction, and their attitudes towards students' beliefs,

$>$ To explore the probable relationship between EFL teachers' job satisfaction and their attitudes towards students' motivation.

According to what mentioned above the following research questions posed:

$>$ Is there a significant relationship between teachers' job satisfaction and their attitudes towards the students' beliefs?

$>$ Is there a significant relationship between teachers' job satisfaction and their attitudes towards the students' motivation?

Also based on the above questions the following hypotheses formulated:

$>$ H01: There is no significant relationship between teachers' job satisfaction and their attitudes towards the students' beliefs.

H02: There is no significant relationship between teachers' job satisfaction and their attitudes towards the students' motivation.

\section{Method}

\subsection{Participants}

Participants of the study were English teachers who had their BA, MA, or PhD degree; teaching in Iranian language institutes in Isfahan. The participants were both female and male teachers ( 81 female, 128 male) who have various years of experience (from a year to 10years and above). It is worth mentioning that in the study gender was not considered a determining factor in choosing the participants.

\subsection{Instruments}

In the study, questionnaire was utilized as the main instrument to collect the required data. The questionnaire used in the study is reported in the following way:

$>$ Rationale and Aim

$>$ Design and Validation

$>$ Structure and Content 
Rationale and aim - The purpose of the questionnaire was to investigate the probable relationship between EFL teachers' job satisfaction, and their attitudes towards students' beliefs, and motivation. The teachers' questionnaire was developed mainly from the following sources:

$>\quad$ Lester's Teachers' Job Satisfaction Questionnaire (TJSQ) (1987);

$>\quad$ Rahimi, Riazi, \&Saif's (2008) Motivation Test; from: Salimi (2000, pp. 74-77);

$>\quad$ Adapted version of the Beliefs about Language Learning Inventory (BALLI) by Horwitz (1982)

Design and validation - Knox (2011) in his dissertation studying how teachers and administrators react when the school is under the stress of an accountability system, mentioned that utilizing questionnaires to gain information of participants' beliefs provide us with many advantages. First, they are economical and can be used anonymously. Second, researchers can use standard questions and uniform procedures. Third, scoring and result is more easier comparatively. A final useful effect of using questionnaires is that the participants have time to think about their responses and are less likely to be influenced by an interviewer (Gay, Mills, \& Airasian, 2006).

In the current study, the questionnaire consisted of two parts to provide the researchers with an overall teachers' job satisfaction and their students' beliefs in and motivation for learning English as a foreign language. The teacher's questionnaire was developed in English, as the participants were teachers of English, and by the researchers (See Appendices A). In the development process of the questionnaire, in order to ensure validity and reliability, the researcher reviewed the relevant literature and examined the questionnaires designed for similar purposes (e.g., Lester, 1987; Rahimi, Riazi, \& Saif's, 2008; Horwitz, 1982). The first draft of the teachers' questionnaire was developed considering the issues pointed in the literature. Two separate forms, content validation form and face validation form, were also designed to check the content and face validity of the questionnaire. Then, the first draft of the questionnaire and two designed forms were sent to two experts to be reviewed in order to ensure the content validity and face validity of the questionnaire.

The content validation form required the experts to rate each item of the questionnaire based on two criteria of the appropriateness of the item in representing the topic, and the clarity of the meaning of the item (see Appendix B). And then, before the data is collected, the developed questionnaire was given to two academicians to judge about the components of visual appeal, quality of instructions to respondents, scoring format, page layout, number of sections, number of items, wording of items, relevance of items, and length of time needed to complete the questionnaire.

Next, the amendments were done based on their suggestions and comments. This ensures the face validity of the scale. Then, the second draft of the questionnaire was piloted on 60 English teachers and Cronbach's alpha coefficient was calculated. The Cronbach's alpha value for all the variables exceeded the minimum required value of 0.7 and hence, the scale of variables is highly reliable.

\section{Table 1}

The Results of the Reliability Test

\begin{tabular}{lccc}
\hline \multicolumn{1}{c}{ Variables } & No. of items & Mean & Cronbach's Alpha \\
\hline Beliefs & 15 & 3.56 & 0.860 \\
Motivation & 15 & 3.57 & 0.889 \\
Job Satisfaction & 15 & 3.57 & 0.821 \\
\hline
\end{tabular}

As shown in Table 1, the Cronbach's alpha value for all the variables exceeded the minimum required value of 0.7 and hence, the scale of variables is highly reliable. In sum, stages of the teachers' questionnaire design and validation procedures can be illustrated in the Figure 1. 


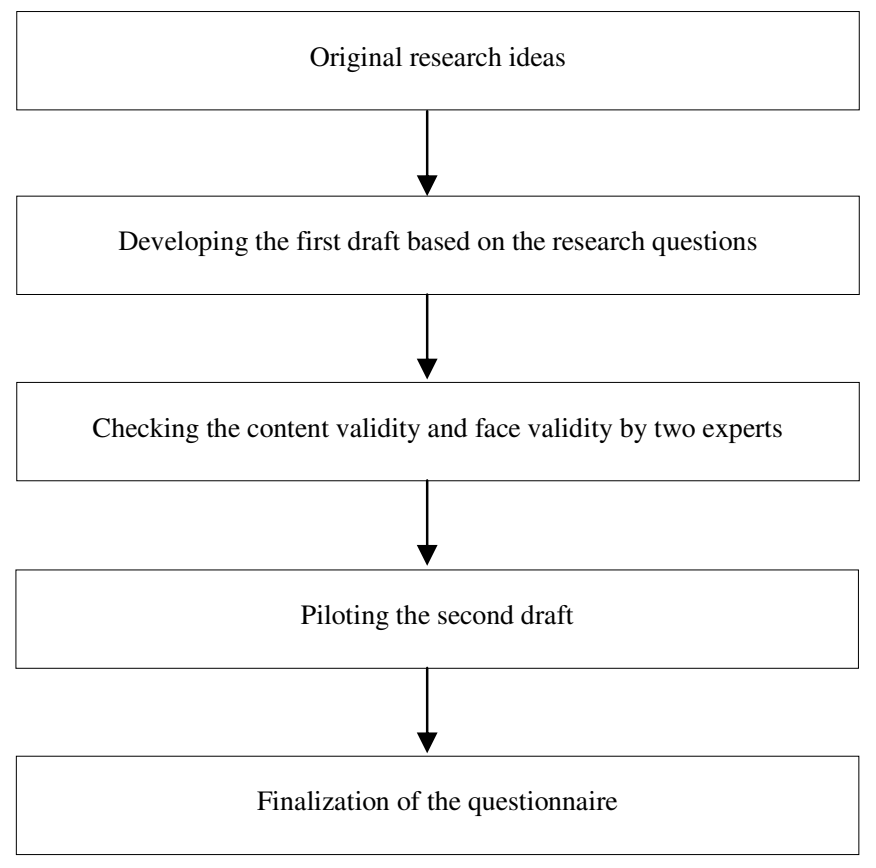

Figure 1. Stages of the teachers' questionnaire design and validation procedures

Structure and content - The teachers' questionnaire consisted of three main parts and was designed and prepared in English. In each part participants were asked to read the statements and then according to their information or opinion decide if they: (1) Strongly disagree, (2) Disagree, (3) Neither agree nor disagree, (4) Agree, (5) Strongly agree. The first part consisted of four questions of teacher personal characteristics related to demographic information, such as gender, age, academic qualifications, and years of teaching experience (see Appendix A).

The second part consisted of 30 items in general. Half of the items of this part were concerning students' beliefs and the second half was related to their motivation towards learning English. In these two parts, teachers were supposed to read each statement and then according to their information about their students decide to provide the answer.

Those questiones related to belifs were dreived from the adapted version of the Beliefs about Language Learning Inventory (BALLI), which is a questionnaire developed by Horwitz(1982) and is adapted to 5 -point Likert scale, ranging from strongly agree to strongly disagree. Furthermore, the student's motivation items used in this study were taken from Rahimi, Riazi, and Saif's (2008) Motivation Test. Here again, the participants selected a number on a five-point Likert scale reflecting their degree of preference or their tendency towards the items of the questionnaire. The choices ranged from 1 "strongly disagree" to 5 "strongly agree".

The last part consisted of fifteen items related to teachers' job satisfaction. In this part, items were developed from Lester's Teachers' Job Satisfaction Questionnaire (1987). Lester developed the teachers' job satisfaction questionnaire (TJSQ) specifically for using in various educational settings. The original questionnaire was made of 66 items in nine subscales and in five-point Likert scale format. The subscales are defined as supervision, colleagues, working conditions, pay, and responsibility, work itself, advancement, security, and recognition. In this part, the factor supervision had one item, colleagues had two items, working conditions had one items, pay had two items, responsibility and work itself both had three items, advancement, security and recognition all had one item.

Structure and themes of items concerning beliefs - Consisting of fifteen items, this part of the questionnaire had five themes: foreign language aptitude, difficulty of language learning, learning and communication 
Teachers' attitudes towards job satisfaction and their students' beliefs and motivation

strategies, nature of language learning, and motivation and expectations. Foreign language aptitude and difficulty of language learning both had three items, learning and communication strategies had four, nature of language learning and motivation and expectations respectively had three and two items.

Structure and themes of items concerning motivation - With regard to the second half of part one, again fifteen items in two themes were established. Students' direction of motivation and students' attitudes toward language learning, language culture, English language, and teaching method are relating themes. Students' direction of motivation had nine items. Explaining in more details, it is possible to say that items 19, 20, and 21 were concerning intensity of motivation, 16, 17, and 18 instrumental motivations, and 22, 23, 24 were related to cognitive motivation. And students' attitudes toward language learning, language culture, English language had six items. More specifically, items 25 and26 were related to academic language learning, items 28 and 29 were about English language, and items 27and 30 teaching method. Table 3.2 shows the structure and themes of the teachers' questionnaire. Table 2 shows the structure and themes of the teachers' questionnaire.

\subsection{Procedure}

Three hundred and forty questionnaires were distributed among the English teachers, teaching in different English language teaching institutes in Isfahan. Since it was a part of the institutes' condition to allow the researchers collect data, the details of the institutes are kept anonymous in all reports generated from the data. After 20 days, 233 questionnaires were collected; however, 24 questionnaires were discarded from the analysis process due to the major data-missing problem and only 209 questionnaires were considered for data entry and data analysis procedures.

\section{Table 2}

Structure and themes of the teachers' questionnaire

\begin{tabular}{|c|c|c|}
\hline Structure & Content & Items \\
\hline Theme One & $\begin{array}{l}\text { Foreign language aptitude(1-6) } \\
\text { The special ability for learning foreign languages } \\
\text { Capability of learning and speaking foreign languages } \\
\text { Difficulty of language learning }\end{array}$ & 6 \\
\hline Theme Two & $\begin{array}{l}\text { Learning and Communication Strategies }(7-9 \& 15) \\
\text { The importance of speaking with an excellent pronunciation } \\
\text { The important to practice with CDs or taps } \\
\text { The importance of error correction and its time }\end{array}$ & 4 \\
\hline Theme Three & $\begin{array}{l}\text { Nature of Language Learning (TQ10-12) } \\
\text { Learning Language and other academic subjects } \\
\text { Learning vocabulary } \\
\text { knowing about English -speaking culture }\end{array}$ & 3 \\
\hline Theme Four & $\begin{array}{l}\text { Motivation and Direction of Motivation (TQ13-24) } \\
\text { The importance of learning English and its providing opportunities } \\
\text { Intensity of motivation } \\
\text { Instrumental motivation } \\
\text { Cognitive motivation }\end{array}$ & 12 \\
\hline Theme Five & $\begin{array}{l}\text { Attitudes toward language (TQ25-30) } \\
\text { Academic language learning } \\
\text { English language and teaching method }\end{array}$ & 6 \\
\hline Theme Six & $\begin{array}{l}\text { Colleagues, recognition, and supervision (TQ } 38,40,39,44) \\
\text { The amount of regulation provided by the administration } \\
\text { Friendships and relationships } \\
\text { Professional support and continual learning support as teachers } \\
\text { Employee attention, appreciation, and prestige }\end{array}$ & 4 \\
\hline Theme Seven & $\begin{array}{l}\text { Work, work condition, security (TQ33,34,36,41,43) } \\
\text { Freedom to implement innovative materials } \\
\text { Utilize one's skills and abilities } \\
\text { The overall physical condition of work environment } \\
\text { Seniority, layoffs, pension, retirement, and dismissal }\end{array}$ & 5 \\
\hline Theme Eight & $\begin{array}{l}\text { Pay (TQ 35,37) } \\
\text { The teacher's annual income } \\
\text { Financial recognition for accomplishments }\end{array}$ & 2 \\
\hline Theme Nine & $\begin{array}{l}\text { Responsibility(TQ 31,32,45) } \\
\text { To make and uphold appropriate working relationships with the students } \\
\text { The teachers' participation in creating and upholding school policies } \\
\text { Accountability for one's own work }\end{array}$ & 3 \\
\hline
\end{tabular}




\section{Results}

\subsection{Demographic Analysis}

The first part consisted of four items of teacher personal characteristics related to demographic information including gender, age, academic qualifications, and years of teaching experience. As shown in Table 3 the majority of the respondents were male, constituting 61.2 percent of the sample.

\section{Table 3}

Respondents' gender profiles

\begin{tabular}{lcc}
\hline \multicolumn{1}{c}{ Gender } & Frequency & Percent \\
\hline Female & 81 & 38.8 \\
Male & 128 & 61.2 \\
\hline
\end{tabular}

Table 4 also illustrate the participants' educational level. As shown, most of the respondents had master degree $(\mathrm{N}=115,55 \%)$, followed by bachelors' degree holders $(\mathrm{N}=66,31.6 \%)$ and only 13.4 percent had $\mathrm{PhD}$.

\section{Table 4}

Respondents' education level

\begin{tabular}{lcc}
\hline \multicolumn{1}{c}{ Education } & Frequency & Percent \\
\hline Bachelors & 66 & 31.6 \\
Masters & 115 & 55.00 \\
PhD & 28 & 13.4 \\
\hline
\end{tabular}

According to Table 5 most of the participants had 1-3 years of work experience ( $\mathrm{N}=178,85.2 \%)$, followed by those having 7-9 years of experience in teaching English $(\mathrm{N}=14,6.7 \%)$. The least number of teaching experience were those who had more than 10 years of experience $(\mathrm{N}=4,1.9 \%)$.

\section{Table 5}

Respondents' years of work experience

\begin{tabular}{lcc}
\hline \multicolumn{1}{c}{ Experience } & Frequency & Percent \\
\hline 1-3 years & 178 & 85.2 \\
4-6 years & 13 & 6.2 \\
7-9 years & 14 & 6.7 \\
10 years and above & 4 & 1.9 \\
\hline
\end{tabular}

As shown in Table 6, most of the respondents had university education in English major $(\mathrm{N}=69,58.5 \%)$.

Table 6

Respondents' major

\begin{tabular}{lccc}
\hline & Frequency & Percent & Mean \\
\cline { 2 - 4 } English & 69 & 58.5 & 1.58 \\
Other Majors & 49 & 41.5 & \\
\hline
\end{tabular}

\subsection{Data Missing and Normality Tests Procedures}

After the demographic analysis, data missing check was conducted to make sure that the data set is complete. Eighteen questionnaires were found to partially have missing data, each with 1-2 items. Since the missing data portion is below $10 \%$, replacement method was done and an average of the next and before question items was calculated and replaced in the missing data. This approach is consistent with Hair et al. (2010). Furthermore, items $34,37,40,44$ were designed in such a way to have reverse answers with other similar items. Before the 
Teachers' attitudes towards job satisfaction and their students' beliefs and motivation

analysis is started, respondents' answers for these questions were coded reversely, as outlined by Hair et al. (2010).

\section{Table 7}

Results of normality test

\begin{tabular}{lccc}
\hline & Beliefs & Motivation & Job Satisfaction \\
\hline Skewness & -0.54 & -0.49 & -0.50 \\
Std. Error of Skewness & 0.22 & 0.22 & 0.22 \\
Z-value & -2.44 & -2.21 & -2.26 \\
Kurtosis & 0.24 & 0.87 & 0.32 \\
Std. Error of Kurtosis & 0.44 & 0.44 & 0.44 \\
Z-value & 0.54 & 1.97 & 0.73 \\
\hline
\end{tabular}

In the next step, the assumption of normal distribution was examined. Table 7 shows the results of the normal distribution test. As shown, the $\mathrm{z}$-value results for the skweness and kurtosis are in the range of -2.56 and +2.56 , as outlined by Hair et al. (2010). This implies that the distribution is normal and there is no violation if normal distribution for this data set.

\subsection{Reliability and validity tests}

As mentioned, before the data is collected, the developed questionnaire was given to two academicians for their comments and opinions and the amendments were done based on their suggestions and comments. This ensures the content and face validity of the scale. After that, a reliability test was utilized, using Cronbach's alpha technique.

\section{Table 8}

The results of the reliability test

\begin{tabular}{lccc}
\hline Variables & No. of items & Mean & Cronbach's Alpha \\
\hline Beliefs & 15 & 3.56 & 0.860 \\
Motivation & 15 & 3.57 & 0.889 \\
Job Satisfaction & 15 & 3.57 & 0.821 \\
\hline
\end{tabular}

As shown in Table 8, the Cronbach's alpha value for all the variables exceeded the minimum required value of 0.7 and hence, the scale of variables is highly reliable.

\subsection{Validation Procedure}

To examine the convergent and discriminant validity of the questionnaire, the confirmatory factor analysis (CFA) technique was applied and the parameters were estimated using the maximum likelihood estimation (MLE) technique using AMOS 5. Before testing the validity, the model goodness-of-fit was examined using different model fit indices proposed by Liu, Marchewka, Lu, and Yu (2004).

These measures are the ratio of Chi-square $(\chi 2)$ to degrees of freedom (d.f.), adjusted goodness of fit (AGFI), non-normalized fit index (NNFI), root mean square error of approximation (RMSEA), comparative fit index (CFI) and root mean square residual (RMSR). During this process, the items 7, 11 to 19, 28 to 33, and 39-45 were omitted due to low factor loading values (below 0.6). The results of measurement model fitness- after the omission of the items with low loadings- are summarized in Table 9.

As shown in Table 9, all the result values meet the recommended value. Having found a good model fit, the validity of the scale can be assessed. 
Salehi, H., \& Taghavi, E.

\section{Table 9}

Fit indices for measurement model

\begin{tabular}{lc}
\hline \multicolumn{1}{c}{ Fit Indices } & Result value \\
\hline$\chi 2$ & 401.21 \\
d.f. & 206 \\
$\mathrm{P}$ & 0.000 \\
$\chi 2 /$ d.f. & 1.948 \\
NNFI & 0.921 \\
CFI & 0.930 \\
RMSEA & 0.067 \\
RMSR & 0.051 \\
AGFI & 0.805 \\
\hline
\end{tabular}

\section{Table 10}

The loadings of the items

\begin{tabular}{llc}
\hline \multicolumn{1}{c}{ Question Items } & Corresponding variable & Loadings \\
\hline Q1 & Belief & 0.764 \\
Q2 & Belief & 0.68 \\
Q3 & Belief & 0.834 \\
Q4 & Belief & 0.809 \\
Q5 & Belief & 0.763 \\
Q6 & Belief & 0.797 \\
Q8 & Belief & 0.736 \\
Q9 & Belief & 0.763 \\
Q10 & Belief & 0.703 \\
Q20 & Motivation & 0.727 \\
Q21 & Motivation & 0.708 \\
Q22 & Motivation & 0.716 \\
Q23 & Motivation & 0.819 \\
Q24 & Motivation & 0.825 \\
Q25 & Motivation & 0.825 \\
Q26 & Motivation & 0.749 \\
Q27 & Motivation & 0.729 \\
Q34 & Satisfaction & 0.699 \\
Q35 & Satisfaction & 0.781 \\
Q36 & Satisfaction & 0.817 \\
Q37 & Satisfaction & 0.727 \\
Q38 & Satisfaction & 0.709 \\
\hline
\end{tabular}

As shown in Table 10, the loading values of items on their corresponding variables were found significant (t-values > 1.96). Furthermore, as illustrated in Table 11, composite reliability (CR) and average variance extracted (AVE) values for all the variables were found to be sufficiently high. Therefore, the convergent validity of the scale was ensured. As shown in Table 9, it was also found that the AVE values of each variable are higher than the square correlation values of the variables.

Table 11

The $C R$ and $A V E$ values

\begin{tabular}{lccccc}
\hline \multirow{2}{*}{ Variables } & \multirow{2}{*}{ CR } & \multirow{2}{*}{ AVE } & & \multicolumn{3}{c}{ Square Correlations } \\
\cline { 4 - 6 } Beliefs & 0.92 & 0.58 & Beliefs & Motivation & Satisfaction \\
Motivation & 0.91 & 0.58 & 0.29 & & \\
Satisfaction & $\mathbf{0 . 8 0}$ & $\mathbf{0 . 5 1}$ & $\mathbf{0 . 1 3}$ & $\mathbf{0 . 1 1}$ & $\mathbf{1}$ \\
\hline
\end{tabular}

Considering the above results, it can be concluded that the scale has sufficient validity. The results of the confirmatory factor analysis have been shown in Figure 2. 

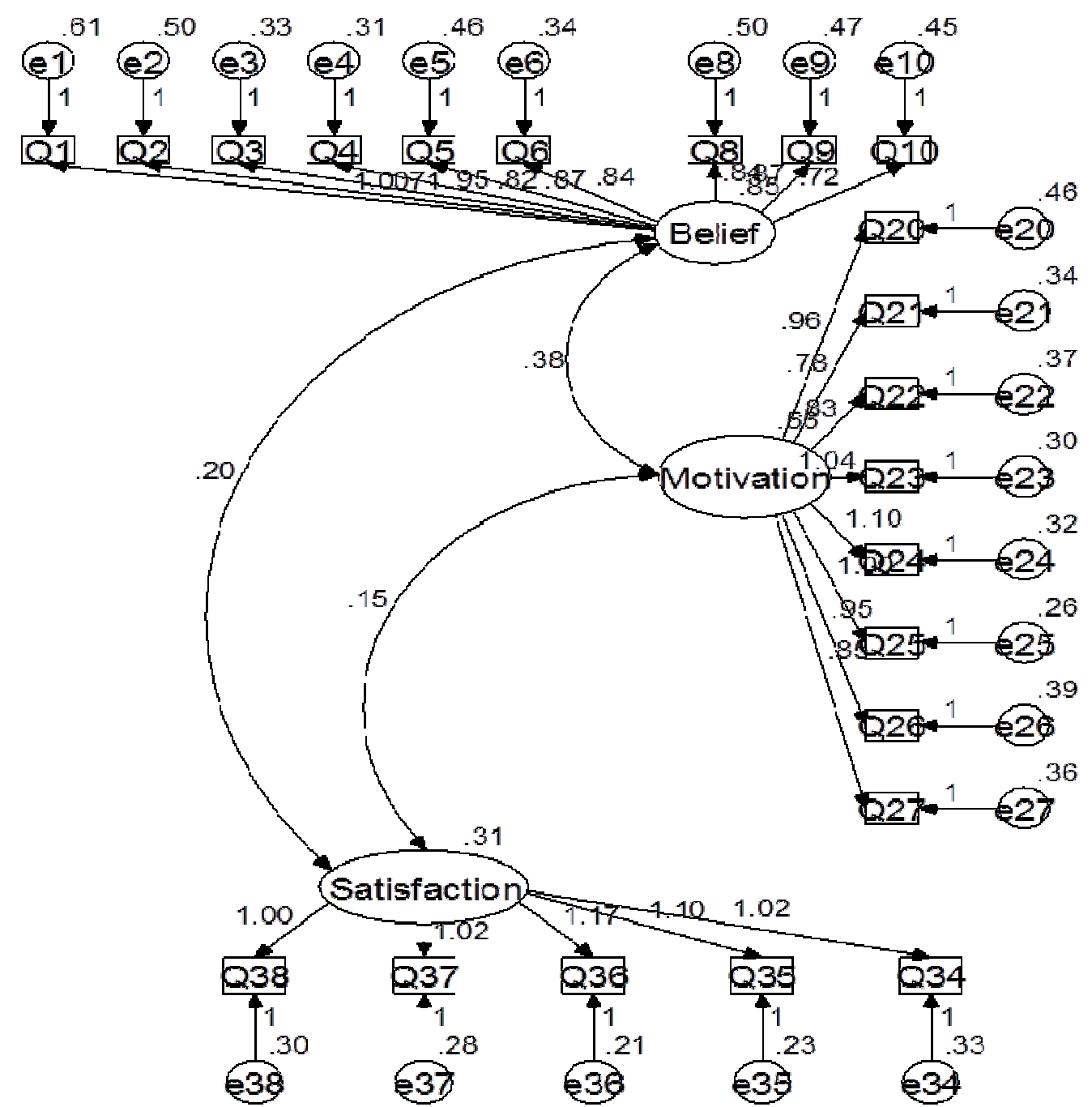

Figure 2. Results of the confirmatory factor analysis

\subsection{Testing the Hypotheses}

Since there are two dependent variables in the model and this research aimed to examine the impact of satisfaction on both dependent variables simultaneously, structural equation modeling (SEM) technique, using AMOS 5 was utilized. First, the goodness of fit for the structural model was tested and as shown in Table 12, the results meet the minimum required values. This indicates that the structural model has a good fit.

Table 12

\begin{tabular}{lc}
\multicolumn{2}{c}{ Structural model fitness results } \\
\hline Fit Indices & Result value \\
\hline$\chi 2$ & 319.188 \\
d.f. & 199 \\
$\mathrm{P}$ & 0.000 \\
$\chi 2 /$ d.f. & 1.604 \\
NNFI & 0.950 \\
CFI & 0.957 \\
RMSEA & 0.054 \\
AGFI & 0.853 \\
\hline
\end{tabular}


The results of the SEM showed that there are empirically positive significant relationships $(t>2.56, p<$ 0.001 ) between teachers' job satisfaction and their students' motivation and beliefs. Therefore, both the hypotheses of this research rejected. The t-values and p-values of the relationships have been shown in Table 13. Moreover, the results of testing the hypotheses are shown in Figure 3.

\section{Table 13}

$T$-Values and P-Value

\begin{tabular}{llcc}
\hline \multicolumn{1}{c}{ Dependent variables } & Independent variable & t-values & P-values \\
\hline Belief & Satisfaction & 5.102 & 0.001 \\
Motivation & Satisfaction & 4.849 & 0.001 \\
\hline
\end{tabular}

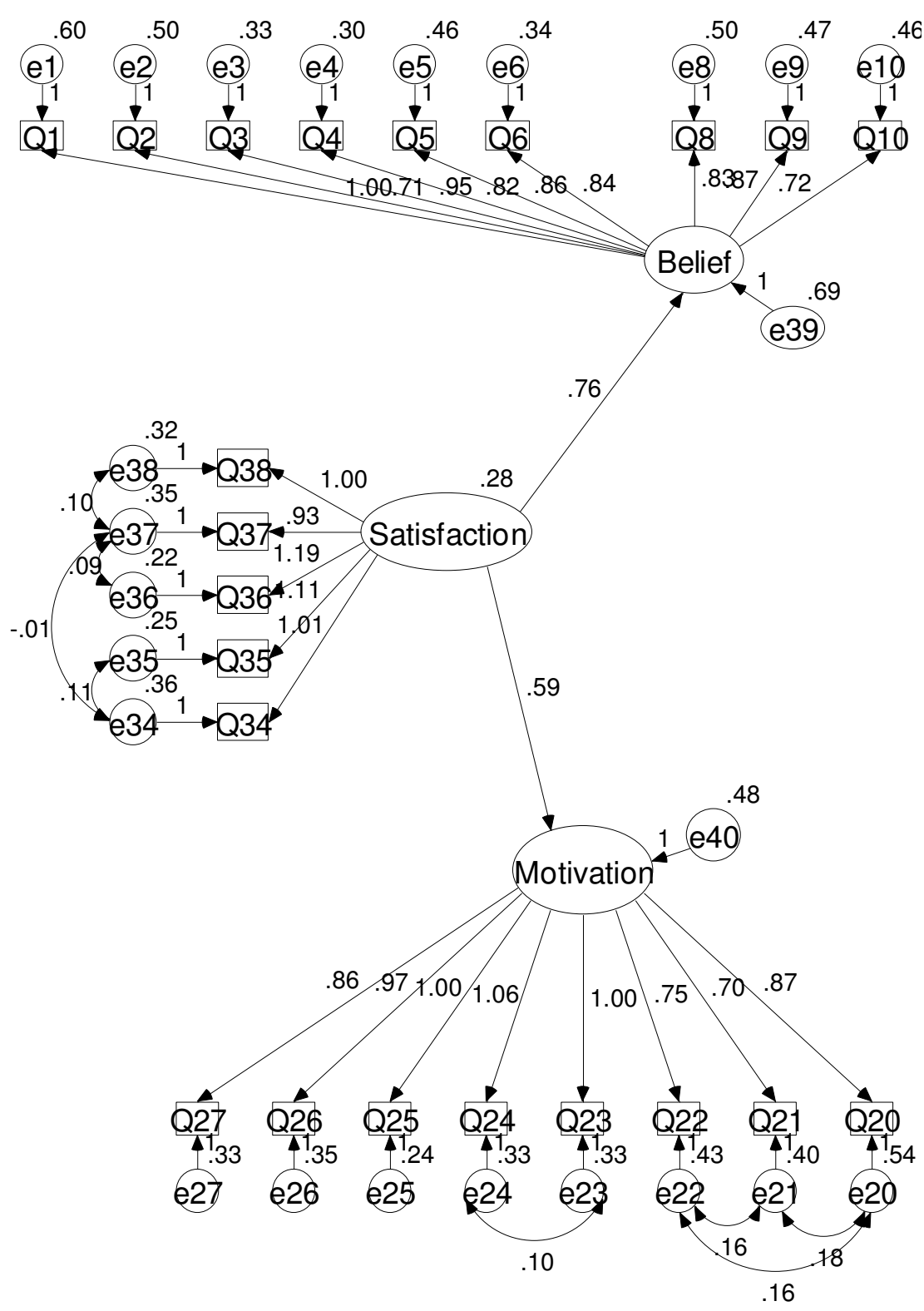

Figure 3. Results of the hypotheses

\section{Discussion and conclusion}

Due to examining the possible relationship of satisfaction and two dependent variables simultaneously, structural equation modeling (SEM) technique was utilized. Accordingly, the findings of the teachers' 
Teachers' attitudes towards job satisfaction and their students' beliefs and motivation

questionnaire clearly indicated that there are empirically positive significant relationships $(t>2.56, p<0.001)$ between teachers' job satisfaction and their students' motivation and beliefs. Therefore, both formulated hypotheses of the study were not empirically supported. To be exact, there is both positive and significant relationship between teachers' job satisfaction and their attitudes towards their students' motivation. Equally, there is a positive significant relationship between teachers' job satisfaction and their attitudes towards their students' beliefs.

The result is in proportion to Kennedy (1996) hypothesizes that teachers' beliefs can form the way teachers behave. As Brown and McGannon (1998) suggested, it is important to help trainees reflect on their beliefs because learners come to class and bring their beliefs to a teacher education program that influence on what and how they learn(Richardson,1996). Also, finding of the study confirmed what McGannon (1998) and Breen (1991) mentioned. They illustrated that teachers had many beliefs about how foreign languages are learned and that influenced their teaching. The Bishay (1996) findings which revealed the significant correlation with job satisfaction and motivation and also Peck, Fox, and Morston (1977) study could be a considered as a support for the finding of the current study.

Peck, Fox, and Morston (1977) studied the relationship between teachers' motivation and students' self-esteem. Based on the finding of the study there is a correlation between teachers' motivation and learners' self-esteem. They added students built high level of self-esteem when they are learning from a teacher holding strong positive attitudes toward teaching. An interesting finding derived from the research, was that students are more likely to think of their teachers as professional or recognize the effectiveness of teachers when their teachers are satisfied with the job. The findings from this study further support Toshiko (2010) assumption which says when teachers perceive their learners become skilled at what they are taught and feel satisfy with their [students] motivation level and growing in learning, they feel satisfied and motivated.

As an academic concept, job satisfaction has always been the center of the researchers' attention in the fields of management, social psychology, and within the educational context. Many studies have been done in the developed countries due to the importance of job satisfaction; however, only a limited number of studies have been conducted on teachers' job satisfaction in Iran. In other words, one of the still uncharted areas in Iran is teachers' job satisfaction and their attitude toward students' beliefs and motivation. To gain better understanding of the nature of such a relationship, two research questions were posed and appropriate research methods were utilized to collect the needed data. The finding of the study clearly indicated that there are empirically positive significant relationships $(t>2.56, p<0.001)$ between teachers' job satisfaction and students' motivation and beliefs. Explicitly, it showed there is positive significant relationship between teachers' job satisfaction and their attitudes towards students' motivation. Equally, there is a positive significant relationship between teachers' job satisfaction and their attitudes towards their students' beliefs.

The same topic could be expanded or narrowed down to different context such as governmental school where teachers are paid by the governmental education system and students have to take the course as compulsory one. These differences may bring different result about and may provide insights into teacher's job satisfaction that teach or intend to teach in those schools.

\section{References}

Amburgey, W. O. (2005). An analysis of the relationship between job satisfaction, organizational culture, and perceived leadership characteristics. Doctoral dissertation, University of Central Florida (UMI No.3188100).

Ashton, P. T., \& Webb, R. B. (1986). Making a difference: Teachers' sense of efficacy and student achievement. New York: Longman.

Beijaard, D., Verloop, N., Vermunt, J. D., (1999). Teachers' perceptions of professional identity: An exploratory study from a personal knowledge perspective. Teaching and Teacher Education, 16, 749-764. 
Salehi, H., \& Taghavi, E.

http://dx.doi.org/10.1016/S0742-051X(00)00023-8

Bernuus, M., Wilson, A. \& Gardner, R. C. (2009). Teachers' motivation, classroom strategy use, students' motivation and second language achievement. AmlainnugeulaVruemz, 12, 25-36.

Caprara, G. V., Barbaranelli, C., Steca, P., \& Malone, P. S. (2006). Teachers' self-efficacy beliefs as determinants of job satisfaction and students' academic achievement: A study at the school level. Journal of School Psychology, 44, 473-490. http://dx.doi.org/10.1016/j.jsp.2006.09.001

Corina, C. C., \&Valerica, A. (2012).Teachers' perceptions and attitudes towards professional activity. Procedia Social and Behavioral Sciences, 51, 167-171. http://dx.doi.org/10.1016/j.sbspro.2012.08.139

Coşkuner, M. (2001). Turkish Provincial State University teachers' perceptions of English language teaching as a career. Retrieved from http://www.thesis.bilkent.edu.tr/0001847.pdf

Currall, S. C., Towler, A. J., Judge, T., \& Kohn, L. (2005). Pay satisfaction and organizational outcomes. Personnel Psychology, 58, 613-640. http://dx.doi.org/10.1111/j.1744-6570.2005.00245.x

Drake, C. (2002). Experience counts: Career stage and teachers' responses to mathematics education reform. Educational Policy, 16, 311-337. http://dx.doi.org/10.1177/0895904802016002004

Dörynei, Z. (2001). Teaching and researching motivation. Essex, England: Pearson Education Limited. Edward Arnold, London.

Eggen, P., \& Kauchak, D. (2002). Strategies for teachers: Teaching content and thinking skills (4th ed.). Needham Heights.

Fenfang, L. (2010). Relationship between EFL Learners' belief and learning strategy use by English majors in vocational colleges. Journal of Language Teaching and Research, 1(6) - 858-866.

Gardner, R., \& Lambert, W. (1959). Motivational variables in second language acquisition. Canadian Journal of Psychology, 13, 266-272. http://dx.doi.org/10.1037/h0083787

Griva,E., Panitsidou, E., \& Chostelidou, D. (2012). Identifying factors of job motivation and satisfaction of foreign language teachers: research project design. Procedia - Social and Behavioral Sciences, 46, 543-547. http://dx.doi.org/10.1016/j.sbspro.2012.05.157

Gritzmacher, J. B., \& Smith, B. P. (1998). Job satisfaction of family and consumer sciences teacher: Implication for teacher shortage, teacher education and in- service education. Journal of Family and Consumer Sciences Education, 16(2), 85. Retrieved from http://www.natefacs.org/Pages/v16no2/16-2-85\%20Smith.pdf

Heidari-Soureshjani, K. S., \& Naseri, N. (2011). The Interrelationship of instrumental, integrative, intrinsic, and extrinsic motivations and the lexical-oriented knowledge among Persian EFL language learners. Theory and Practice in Language Studies, 1(6), 662-670.

Hong, K. (2006). Beliefs about language learning and language learning strategy use in an EFL context: A comparison study of monolingual Korean and bilingual Korean-Chinese university students. Doctoral dissertation, Denton, Texas. Retrieved from http://digital.library.unt.edu/ark:/67531/metadc5270/

Hong Goo, K. (2011). Job satisfaction among Korean academics: A critical investigation. Doctoral dissertation, University of Nottingham. Retrieved from http://eprints.nottingham.ac.uk/id/eprint/12976

Horwitz, E. K. (1987). Surveying student beliefs about language teaming. In A. L.Wenden \& J. Robin (Eds.), Learner strategies in language learning (pp. 119-132).London: Prentice Hall.

Hughes, V. M. (2006). Teacher evaluation practices and teacher job satisfaction. Doctoral dissertation, The Faculty of the Graduate School University of Missouri-Columbia. Retrieved from http://hdl.handle.net/10355/4468

ImaniNojani, M., Arjmandnia, A. A., Afrooz, G. A., \& Rajabi, M. (2012).The study on relationship between organizational justice and job satisfaction in teachers working in general, special and gifted education systems. Procedia - Social and Behavioral Sciences, 46, 2900 - 2905. http://dx.doi.org/10.1016/j.sbspro.2012.05.586

Ispir, O. A. (2010). Teachers' burnout levels and their attitudes towards teaching profession. EABR \& ETLC Conference Proceedings (pp. 229-233). Dublin, Ireland.

Kalleberg, A. L. (1977). Work values and job rewards - Theory of job satisfaction. American Sociological Review, 42, 124-143. http://dx.doi.org/10.2307/2117735 
Teachers' attitudes towards job satisfaction and their students' beliefs and motivation

Kern, R. G. (1995). Students' and teachers' beliefs about language learning. Foreign Language Annals, 28(1), 71-92. http://dx.doi.org/10.1111/j.1944-9720.1995.tb00770.x

Klassen, R. M., \& Ming Ming, C. (2010). Effects on teachers' self-efficacy and job satisfaction: teacher gender, years of experience, and job stress. Journal of Educational Psychology, 102(3), 741-756. http://dx.doi.org/10.1037/a0019237

Kormos, J., Kiddle, T., \& Csizér, K. (2011). Goals, attitudes and self-related beliefs in second language learning motivation: An interactive model of language learning motivation. Applied Lingustics, 32(5), 495. http://dx.doi.org/10.1093/applin/amr019

Kozkoski, W. (2002). Motivation to teach English: A study of EFL instructors in Japan. Unpublished paper presented at The 4th Temple University Japan Applied Linguistics Colloquium.

Landy, F. J. (1989). Psychology of work behavior. Pacific Grove. CA: Brooks/Cole.

Locke, E. A. (1976). The nature and causes of job satisfaction. In M. C. Dunnette (Ed.), Handbook of industrial and organizational psychology (pp. 1297-1349). Chicago, IL: Rand McNally.

Merdassa, A. B. (2012). Assessment of the attitude of prospective teachers enrolled in postgraduate diploma in teaching: The case of Wollega University. Science, Technology and Art Research Journal, 1(4), 65-73. Retrieved from http://www.ajol.info/index.php/star/article/view/98827 http://dx.doi.org/10.4314/star.v1i4.98827

Miskel, C., McDonald, D., \& Bloom, S. (1983). Structural and expectancy linkages within schools and organizational effectiveness. Educational Administration Quarterly, 19, 49-82. http://dx.doi.org/10.1177/0013161X83019001004

Moorman, R. H. (1993). The influence of cognitive and affective based job satisfaction measures on the relationship between satisfaction and organizational citizenship behavior. Human Relations, 6, 759-776. http://dx.doi.org/10.1177/001872679304600604

Nguni, S., Sleegers, P., \& Denessen, E. (2006). Transformational and transactional leadership effects on teachers' job satisfaction, organizational commitment, and organizational citizenship behavior in primary schools: The Tanzanian case. School Effectiveness and School Improvement, 17, 145-177. http://dx.doi.org/10.1080/09243450600565746

Ormrod, J. E. (2008). Educational psychology: Developing learners (6th ed.). New York: Pearson/Prentice Hall.

Papastamatis, A., Panitsidou, E., Giavrimis P., \& Papanis, E. (2009). Facilitating teachers' and educators' effective professional development. Review of European Studies, 1(2), 83-90. http://dx.doi.org/10.5539/res.v1n2p83

Perie, M. \& Baker, D. P. (1997). Job satisfaction among America's teachers: Effects of workplace conditions, background characteristics, and teacher compensation. Statistical analysis report. (ERIC Document Reproduction Service No. ED 412 181).

Pintrich, P. R., \& De Groot, E. V. (1990). Motivational and self-regulated learning components of classroom academic performance. Journal of Educational Psychology, 82(1), 33-40. http://dx.doi.org/10.1037/0022-0663.82.1.33

Pintrich, P. R. \& Schunk, D. H. (2002). Motivation in education: Theory, research, and application (2nd ed.). Upper Saddle River, NJ: Prentice Hall.

Roeser, R., Arbreton, A., \&Anderman, E. (1993). Teacher characteristics and their effects on student motivation across the school year. Paper presented at the annual meeting of the American Educational Research Association, Atlanta.

Roethlisberger, F. J., \& Dickson. W. J. (1939). Management and the worker. Cambridge. MA: Harvard University Press.

Ryan, R. M., \& Deci, E. L. (2000).Self-determination theory and the facilitation of intrinsic motivation, social development, and well-being. American Psychologist, 55, 68-78. http://dx.doi.org/10.1037/0003-066X.55.1.68

Spector, P. E. (1997). Job satisfaction: Application, assessment, causes and consequences. Thousand Oaks, CA: SAGE.

Schumann, F. M. (1980). Diary of a language learner: A further analysis. In R. C. Scarcella \& S. D. Krashen 
Salehi, H., \& Taghavi, E.

(Eds.), Research in second language acquisition: Selected papers of the Los Angeles second language acquisition research forum (pp. 51-57). Rowley, MA: Newbury House.

Schumann, F. M., \& Schumann, J. H. (1977). Diary of a language learner: An introspective study of second language learning. In H. D. Brown, C. A. Yorio, \& R. H. Crymes (Eds.), On TESOL '77 - Teaching and learning English as a second language: Trends in research and practice (pp. 241-249). Washington, DC.

Thompson, E. R., \& Phua, F. T. T. (2012). A brief index of affective job satisfaction. Group \& Organization Management, 37(3), 275-307. http://dx.doi.org/10.1177/1059601111434201

Thoonen, E. E. J., Sleegers, P. J.C., Peetsma, T. T. D, \& Oort, F. J. (2010). Can teachers motivate students to learn? Educational Studies, 73(3), 345-360.

Tziava, K. (2003). Factors that motivate and demotivate Greek EFL teachers. Doctoral dissertation, The University of Edinburgh, Moray House School of Education. Retrieved from http://hdl.handle.net/1842/495

Ushioda, E. (2003). Motivation as a socially mediated process. In D. Little, J. Ridley \& E. Ushioda (Eds.), Learner autonomy in the foreign language classroom: Teacher, learner, curriculum and assessment (pp. 90- 102). Dublin: Authentic.

Wesely, M. (2012). Learner attitudes, perceptions, and beliefs in language learning. Foreign Language Annals, 45 (1), 98-117. http://dx.doi.org/10.1111/j.1944-9720.2012.01181.x

Weiss, H. M. (2002). Deconstructing job satisfaction setting evaluations, beliefs, and affective experiences. Human Resource Management Review, 12(2), 173-194.

http://dx.doi.org/10.1016/S1053-4822(02)00045-1 


\section{Appendix A}

Dear Teachers,

The researcher wish you answer this questionnaire carefully.All responses provided will be confidential and used for research purposes only.The questionnaireconsists of two parts .In the first part please read each statements and then according to your information about your students and the experience you have in relation with them, decide if you : (1) Strongly disagree,(2) Disagree,(3) Neither agree nor disagree,(4) Agree,(5) Strongly agree.

And in the second part, please read each statements and then decide if you : (1) Strongly disagree,(2) Disagree,(3) Neither agree nor disagree,(4) Agree,(5) Strongly agree. There are no right or wrong answer; the researcher is simply interested in your opinions.

Thank you for taking time to complete.

1. Gender: Female Male

2. Educational status: BA MA $\mathrm{PhD}$

3. Years of experience: 1-3 4-6 $7-9$ 10 and above

4. Your major at college: English other subjects

\section{Part One:}

Please read each statements and then according to your information about your students, decide if you : (1) Strongly disagree,(2) Disagree,(3) Neither agree nor disagree,(4) Agree,(5) Strongly agree.

\begin{tabular}{|c|c|c|c|c|c|}
\hline & $\begin{array}{l}\text { Strongly } \\
\text { disagree }\end{array}$ & disagree & $\begin{array}{l}\text { Neither } \\
\text { agree nor } \\
\text { disagree }\end{array}$ & agree & $\begin{array}{l}\text { Strongly } \\
\text { agree }\end{array}$ \\
\hline $\begin{array}{l}\text { 1. Some of my students believe it is easier for children than adults to } \\
\text { learn a foreign language. }\end{array}$ & & & & & \\
\hline $\begin{array}{l}\text { 2. Based on my students' opinion, some people have a special ability } \\
\text { for learning foreign language. }\end{array}$ & & & & & \\
\hline $\begin{array}{l}\text { 3. Everyone can learn to speak a foreign language, according to my } \\
\text { students' view. }\end{array}$ & & & & & \\
\hline $\begin{array}{l}\text { 4. Some of the students think that some languages are easier to learn } \\
\text { than others are. }\end{array}$ & & & & & \\
\hline 5. My students believe that they will learn to speak English well. & & & & & \\
\hline $\begin{array}{l}\text { 6. Some of my students believe that it is easier to speak than to } \\
\text { understand a foreign language. }\end{array}$ & & & & & \\
\hline $\begin{array}{l}\text { 7. My students think that it is important to speak English with an } \\
\text { excellent pronunciation. }\end{array}$ & & & & & \\
\hline $\begin{array}{l}\text { 8. According to some of my students, if beginning students are } \\
\text { allowed to make errors in English, it will be difficult for them to } \\
\text { speak correctly later on. }\end{array}$ & & & & & \\
\hline $\begin{array}{l}\text { 9. My students believe that it is important to practice with CDs or } \\
\text { taps. }\end{array}$ & & & & & \\
\hline $\begin{array}{l}\text { 10. In my students' opinion, learning a foreign language is different } \\
\text { from learning other academic subjects. }\end{array}$ & & & & & \\
\hline $\begin{array}{l}\text { 11. It is necessary to know about English -speaking culture in order } \\
\text { to speak English, according to my students' opinion. }\end{array}$ & & & & & \\
\hline $\begin{array}{l}\text { 12. Some of my students think that the most important part of } \\
\text { learning foreign language is learning vocabulary. }\end{array}$ & & & & & \\
\hline $\begin{array}{l}\text { 13. My students believe that if they learn English well, they will } \\
\text { have better opportunities for a good job. }\end{array}$ & & & & & \\
\hline $\begin{array}{l}\text { 14. Some of the students in Iran feel that it is important to speak } \\
\text { English. }\end{array}$ & & & & & \\
\hline $\begin{array}{l}\text { 15. Some of my students believe that they should not say anything } \\
\text { in English until they can say it correctly. }\end{array}$ & & & & & \\
\hline
\end{tabular}


Salehi, H., \& Taghavi, E.

\begin{tabular}{|c|c|c|c|c|c|}
\hline & $\begin{array}{l}\text { Strongly } \\
\text { disagree }\end{array}$ & disagree & $\begin{array}{l}\text { Neither } \\
\text { agree nor } \\
\text { disagree }\end{array}$ & agree & $\begin{array}{l}\text { Strongly } \\
\text { agree }\end{array}$ \\
\hline \multicolumn{6}{|l|}{$\begin{array}{l}\text { 16. Some of my students would like to learn English because they } \\
\text { would like to teach it. }\end{array}$} \\
\hline \multicolumn{6}{|l|}{$\begin{array}{l}\text { 17. As far as I know, my students thinks learning a foreign language } \\
\text { makes them a more knowledgeable person. }\end{array}$} \\
\hline \multicolumn{6}{|l|}{$\begin{array}{l}\text { 18. According to my students, other people think more highly of } \\
\text { them if they know a foreign language. }\end{array}$} \\
\hline \multicolumn{6}{|l|}{$\begin{array}{l}\text { 19. Some of my students say that they like English more than other } \\
\text { subjects do. }\end{array}$} \\
\hline \multicolumn{6}{|l|}{$\begin{array}{l}\text { 20. They would like to have more personal practice in their English } \\
\text { course, based on my students' opinion. }\end{array}$} \\
\hline \multicolumn{6}{|l|}{$\begin{array}{l}\text { 21. Some of my students say in their English study, they get through } \\
\text { hard work. }\end{array}$} \\
\hline \multicolumn{6}{|l|}{ 22. My students are curious about English. } \\
\hline \multicolumn{6}{|l|}{$\begin{array}{l}\text { 23. Some of my students say that they would like to learn English } \\
\text { perfectly. }\end{array}$} \\
\hline \multicolumn{6}{|l|}{$\begin{array}{l}\text { 24. According to my students, they would choose to learn English } \\
\text { even if it weren't compulsory. }\end{array}$} \\
\hline \multicolumn{6}{|l|}{ 25. Some of my students think academic learning is pleasant. } \\
\hline \multicolumn{6}{|l|}{$\begin{array}{l}\text { 26. In some of my students' opinion, if they could choose, they } \\
\text { would take more courses in English, }\end{array}$} \\
\hline \multicolumn{6}{|l|}{ 27. Some of my students find our English teaching methods useful. } \\
\hline \multicolumn{6}{|l|}{ 28. Some of the students say /think they love the sound of English. } \\
\hline \multicolumn{6}{|l|}{$\begin{array}{l}\text { 29. My students think it is useful to know the inner structure of } \\
\text { English. }\end{array}$} \\
\hline 30. Some of my students find our English teaching methods boring. & & & & & \\
\hline
\end{tabular}

\section{Part Two:}

Please read each statements and then, decide if you: (1) Strongly disagree,(2) Disagree,(3) Neither agree nor disagree,(4) Agree,(5) Strongly agree.

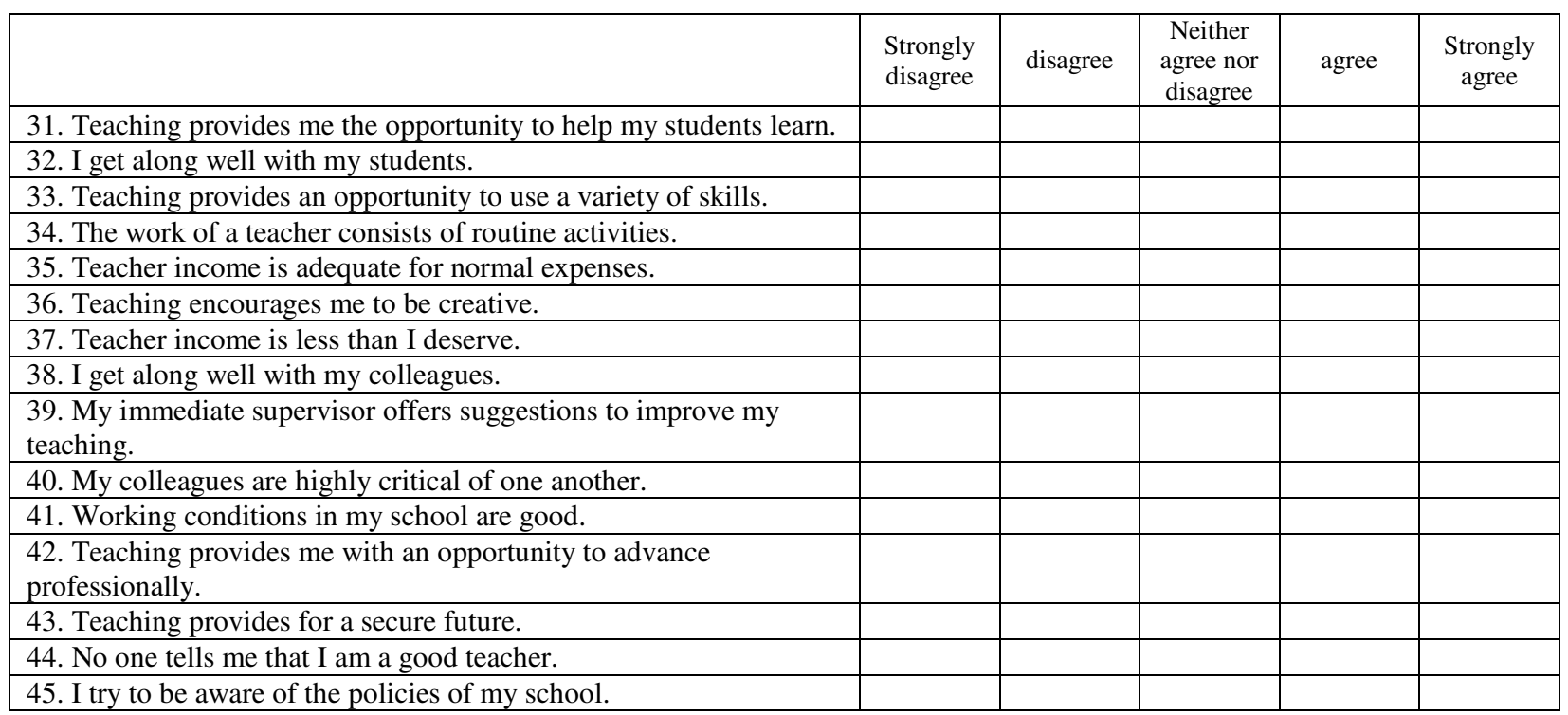




\section{Appendix B}

\section{COVER LETTER TO PANEL OF EXPERTS}

Dear Professors,

I am currently in the process of ascertaining the content and face validity of a questionnaire as main instrument that will be used for collecting data for the study. I really appreciate your serving on my panel of experts to help determine the content, face validity of my survey questionnaires, and interview protocol.

The questionnaire items will be administered to the Iranian EFL teachers teaching in Isfahan institute. The purpose of this study is to investigate the relationship between teachers' job satisfaction and teachers' attitudes towards their students' beliefs and motivation. The teachers' questionnaire consisted of three main parts and was designed and prepared in English. In each part participants were asked to read each statements and then according to their information or opinion decide if they: (1) Strongly disagree, (2) Disagree, (3) Neither agree nor disagree, (4) Agree, (5) Strongly agree. The first part consisted of four questions of teacher personal characteristics related to demographic information, such as gender, age, academic qualifications, and years of teaching experience. The second part consisted of 30 items in general. Half of the items concerning students' beliefs and the second half was related to their motivation towards learning English. In these two parts teachers were supposed to read each statement and then according to their information about their students decide to provide the answer. The last part consisted of fifteen questions related to teachers' job satisfaction. In this part items was developed from Lester's Teachers' Job Satisfaction Questionnaire (1987).

I have designed two special forms for your use in commenting on the items I have developed for the instruments. As you review the proposed items, please feel free to comment based upon the following criteria:

\begin{tabular}{ll}
\hline Face validity & Does the instrument "look like" it is measuring what it is supposed to measure? \\
\hline Content validity & Are the items representatives of concepts related to the thesis topic? \\
Clarity & Is each item in the instruments clear? Is the language/wording appropriate? \\
Format & Logical flow? Suggestions? \\
Other & Please make any additional suggestions as warranted. \\
\hline Delete those items you feel inappropriate.
\end{tabular}

Thank you in advance for your great help.

Yours sincerely,

ElhamTaghavi,

English Department

Faculty of Humanities Najafabad Branch, Islamic Azad University 
Salehi, H., \& Taghavi, E. 